\title{
QUANTITATIVE STUDIES OF THE INTERACTION BETWEEN PROGESTERONE AND PREGNANT MARE SERUM ON OVARIAN FUNCTION IN THE EWE
}

\author{
D. R. LAMOND* \\ C.S.I.R.O., Division of Animal Physiology, Pastoral Research Laboratory, \\ Armidale, N.S.W., Australia
}

(Received 13th August 1963)

\begin{abstract}
Summary. Injections of progesterone were given to ewes to suppress ovarian cycles; pregnant mare serum gonadotrophin (PMS) was administered within 2 days of the final injection of progesterone. Oestrus, numbers of ovulations and follicle growth were observed during the week following treatment. In some experiments, ewes were mated to fertile rams and fertility and fecundity were recorded. Experiments were carried out at different stages of the breeding season.

Relationships between methods of suppression of ovarian cycles (dose and frequency of injections of progesterone) and methods of ovarian stimulation (dose and time of administration of PMs in relation to the final progesterone injection) for each of the responses were examined. The most important finding was that for comparable dosage levels of PMS, the numbers of ovulations were greater after progesterone injections on alternate days than after daily injections. Stage of the breeding season and introduction of rams influenced the results.
\end{abstract}

\section{INTRODUCTION}

Pregnant mare serum has been used to increase fecundity in the ewe during the breeding season (Robinson, 1951; Wallace, 1954; Gordon, 1958a), and to augment fertility during anoestrus (Dutt, 1953; Robinson, 1954; Gordon, $1958 b)$. During the breeding season, PMs is given on the 12th to 14th day after oestrus, when the production of progesterone by the corpus luteum may be expected to be declining or about to decline (Edgar \& Ronaldson, 1958). A single injection of PMS will induce ovulation in the anoestrous ewe (Cole \& Miller, 1933), but progesterone priming is considered essential for reasonable fertility (Robinson, 1955, 1959). Progesterone treatment is used during the breeding season to synchronize oestrus and ovulation prior to artificial insemination, and PMS is given 0 to 2 days after the progesterone to reduce variation between ewes. However, fertility varies greatly with this type of treatment (Robinson, 1956, 1958, 1961; Davies \& Dun, 1957; Davies, 1960; Lamond, 1960, 1962a).

* Present address: C.S.I.R.O., Division of Animal Physiology, Cunningham Laboratory, Mill Road, St. Lucia, Queensland, Australia. 
It seems likely that a time-dose relationship may exist between progesterone and PMS that will give high fertility, but quantitative information is lacking. Braden, Lamond \& Radford (1960) showed that the time of onset of oestrus was determined by the kind of progesterone treatments whereas the time of ovulation was largely controlled by the time of injection of ovulating hormone. They also commented that PMS may have predominantly follicle-stimulating or predominantly ovulating action depending on dose and time of injection. Lamond (1962b) examined the interaction between progesterone, PMs and human chorionic gonadotrophin treatments further, with special emphasis on the influence of season.

This paper describes a series of experiments that provide quantitative information on the interaction between progesterone and PMs particularly as influenced by stage of the breeding season. The experiments are described in detail in chronological order, since each of the first three experiments was designed separately to examine certain aspects of the interaction. The fourth experiment was carried out primarily to test the hypothesis that numbers of ovulations were affected by the frequency of progesterone injections, over the last 4 days of treatments.

\section{EXPERIMENTS AND RESULTS}

\section{EXPERIMENT 1-FEBRUARY 1960}

\section{Methods}

Forty-three 2- to 3-year-old Romney-Cheviot ewes were injected intramuscularly with $20 \mathrm{mg}$ of progesterone in oil per ewe at 8.00 to $9.00 \mathrm{a} . \mathrm{m}$. every other day for 12 days (i.e. seven injections). The last injection was on 27th February 1960 (Day 0), and on the next day (Day 1) two of four groups to which the ewes were allotted at random, were given either 250 or 750 nominal units of PMS (freeze-dried whole serum) subcutaneously. The remaining two groups of ewes received similar treatments on Day 2. The PMs doses were equivalent to 500 or 1500 i.u. on the basis of the mouse uterine weight assay (Claringbold \& Lamond, 1957). The experiment was thus a $2 \times 2$ factorial. Two fertile Cheviot rams wearing 'Siresine' marking harness (Radford, Watson \& Wood, 1960) were joined with the ewes on Day 0 and removed 1 week later. On Day 6, laparotomy (Lamond \& Urquhart, 1961) was carried out on sixteen ewes (four from each group) in order to obtain an estimate of the numbers of ovulations that resulted from the treatments. The sheep were on pasture throughout the period of the experiment. The ewes were examined twice daily during the lambing period.

\section{Results}

Of the ewes examined by laparotomy, thirteen had one or two ovulations, and three had not ovulated. Twelve ewes, including the three that had not ovulated, had been in oestrus. Follicles greater than $0.75 \mathrm{~cm}$ in diameter were observed in numerous ewes. There were no differences between treatments in numbers of ovulations, but the groups receiving the higher dosage level of PMS contained up to six large follicles per ewe on the day of laparotomy. Five of 
the sixteen ewes lambed - three had single lambs and two had twins. This compared favourably with nine ewes lambing of the twenty-one remaining ewes that were mated, hence it seems unlikely that the laparotomy affected fertility.

The mating and lambing results are shown in Table 1. There were no significant differences between treatments in the numbers of ewes mated or numbers of lambs born, but there was a tendency towards fewer lambs when PMS was given $48 \mathrm{hr}$ after the final injection of progesterone. The higher dose of PMs given on Day 1 resulted in four sets of twins from five ewes lambing whereas the lower dose resulted in only one set of twins.

TABLE 1

MATING AND LAMBING RESULTS FOR THE EWES TREATED IN FEBRUARY 1960 (EXPERIMENT 1)

\begin{tabular}{|c|c|c|c|c|}
\hline & \multicolumn{4}{|c|}{$\begin{array}{c}\text { Time of injection of PMs in relation to final } \\
\text { injection of progesterone: }\end{array}$} \\
\hline & \multicolumn{2}{|c|}{$24 \mathrm{hr}$ later } & \multicolumn{2}{|c|}{$48 \mathrm{hr}$ later } \\
\hline & $500 *$ & 1500 & 500 & 1500 \\
\hline $\begin{array}{l}\text { No. of ewes per group } \\
\text { No. mated } \\
\text { No. lambed: twins } \\
\text { singles } \\
\text { Total } \\
\text { Total lambs }\end{array}$ & $\begin{array}{r}12 \\
9 \\
1 \\
4 \\
5 \\
6\end{array}$ & $\begin{array}{r}10 \\
9 \\
4 \\
1 \\
5 \\
9\end{array}$ & $\begin{array}{r}10 \\
7 \\
2 \\
0 \\
2 \\
4\end{array}$ & $\begin{array}{r}11 \\
8 \\
1 \\
1 \\
2 \\
3\end{array}$ \\
\hline
\end{tabular}

\section{Methods}

EXPERIMENT 2-MAY 1961

Three hundred Merino ewes of mixed ages were placed in yards in midApril 1961, and offered a grain-chaff ration ad libitum. Entire harnessed rams were joined with the ewes on Ist May. On 8th May, 128 of the ewes that had not been in oestrus (i.e. had not been 'marked' by the rams) were segregated from the main mob and on 11 th May they received the first of a series of seven intramuscular injections of $12.5 \mathrm{mg}$ of progesterone, in arachis oil, per ewe. The injections were given every 2 nd day at 8.00 to 9.00 a.m. After injection on 23rd May, the ewes were randomly allotted to sixteen groups. The experimental plan was a $2^{2} \times 2^{2}$ factorial. The treatments were: two dosage levels of progesterone given either daily or at intervals of 2 days; two dosage levels of PMs given either 2 days before the final injection of progesterone or on the final day of injections. The date of the final injection of progesterone was 27th May (Day 0). The differences between progesterone treatments therefore referred only to the period of the 4 days from 24th May (Day -3) to 27th May. The plan of the experiment is shown in Table 2.

There were eight ewes per treatment. The PMs solutions were prepared on Day -2 and those for use on Day 0 were stored in a refrigerator. Loss of potency is unlikely under such conditions (Lamond, 1957). A dose of PMs was 
given subcutaneously at 11.00 a.m. on Days -2 and 0 . The PMs preparation used in this and subsequent experiments was a commercial purified preparation -Serogan (British Drug Houses Ltd). The material had the stated potency when tested against the International Standard by the mouse uterine weight assay of Claringbold \& Lamond (1957).

On the afternoon of Day -1 , six harnessed vasectomized rams were joined with the flock. The flock was examined twice daily for signs of oestrus. Until Day 6, ewes in oestrus were removed and mated in separate pens by entire rams. From Day 6 to Day 23, when observations ceased, the entire rams ran with the flock. Birth dates of lambs were recorded. For ewes mated at two oestrous periods during the observations conception dates were taken as the dates which coincided most closely with a gestation length of 150 days.
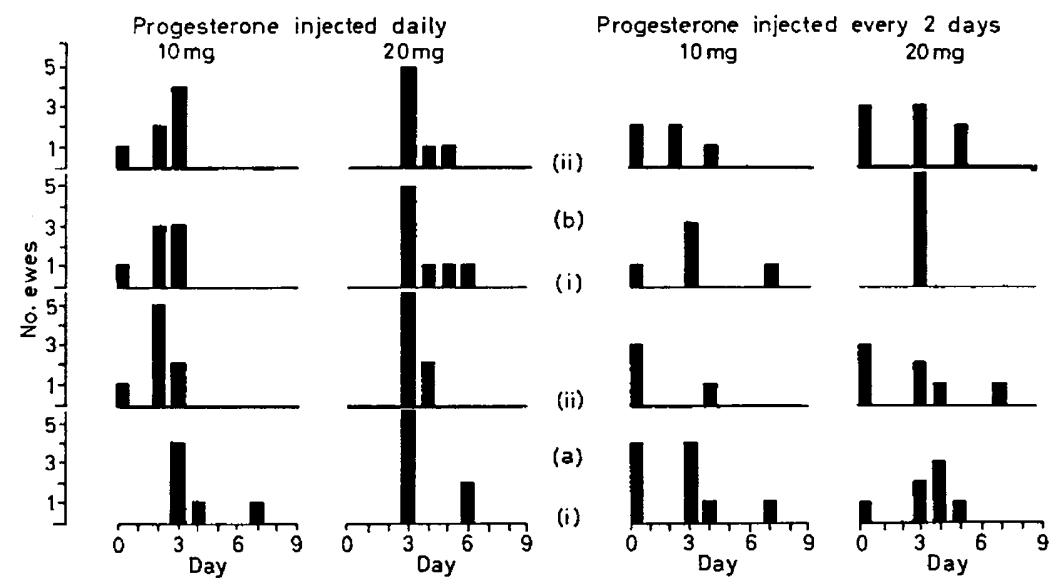

Text-FIg. 1. Number of ewes exhibiting oestrus in Experiment 2. Rams were joined with the ewes on Day - 1. The final injection of progesterone was given on Day 0 . PMs injection (a) Day -2, (b) Day 0; (i) 500 i.u., (ii) 1500 i.u.

\section{Results}

At 8.00 a.m. on Day 0, sixteen ewes had clear raddle marks on the rump, denoting oestrus, and four additional ewes came into oestrus after 9.00 a.m. Nevertheless, all ewes were given their appropriate hormonal treatments that day. The sixteen ewes in oestrus before 8.00 a.m. were joined with rams at midday but only six mated, and the others, though they attracted the rams, would not stand for service. Three of four ewes which came into oestrus after 9.00 a.m. were mated at 5.00 p.m. No ewes were in oestrus at 9.00 a.m. on Day 1. On the basis of previous work (Lamond \& Lambourne, 1961) oestrus was expected to commence on Day 2 and most ewes, including seven of those exhibiting oestrus on Day 0, came into oestrus during the period Day 2 to Day 6 , and particularly on Day 3. These results are shown in Table 2 and Text-fig. 1 and have been referred to in a previous communication (Lamond, 1962c). The relationship between the anomalous oestrous periods and the method of suppression of ovarian cycles (i.e. dose $\times$ frequency of progesterone injections) is clearly seen. 
Ovarian function in the erwe

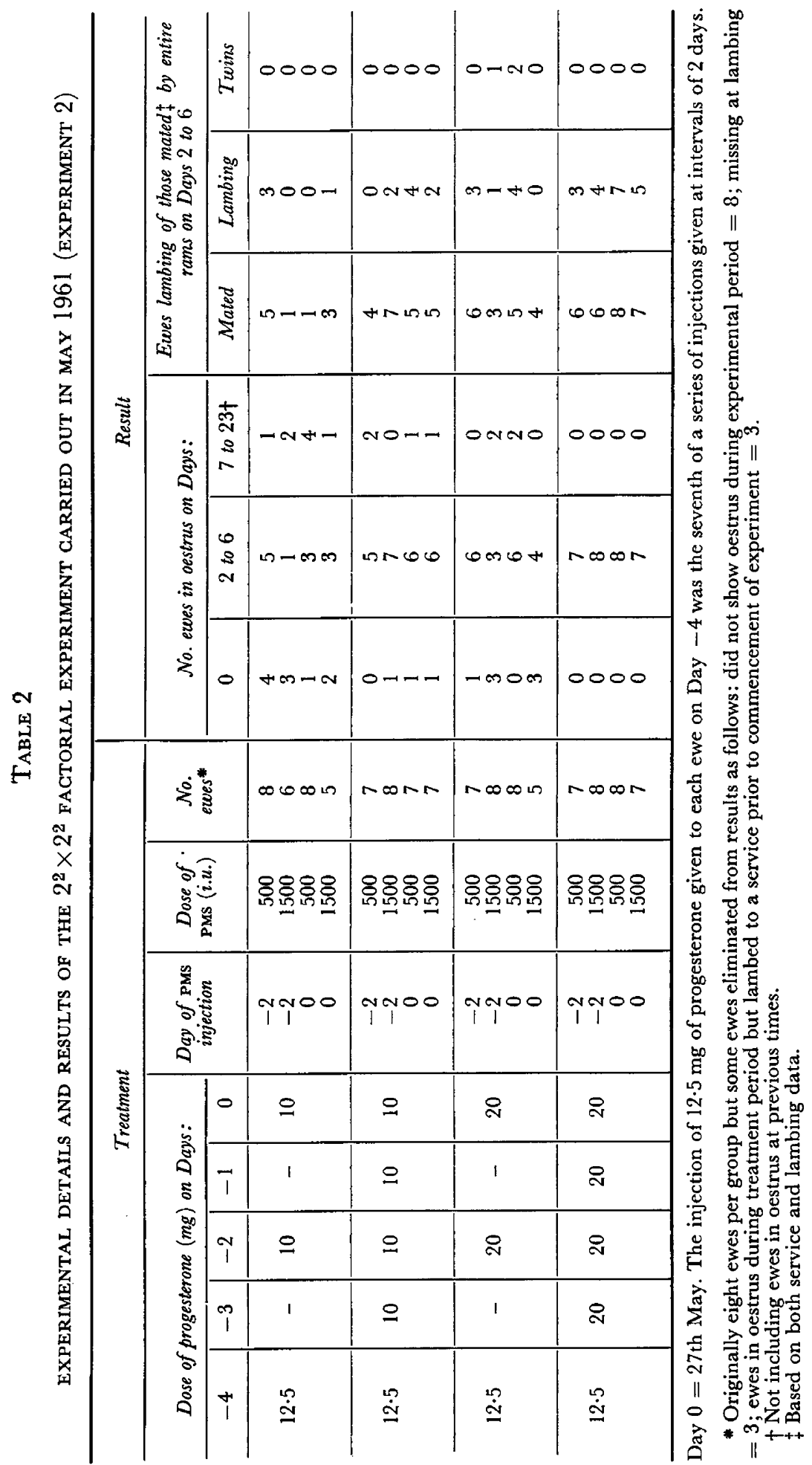


The numbers of ewes that lambed as a result of mating over the period Day 2 to Day 6 are also shown in Table 2; only three ewes had twins. The original design of this experiment called for an analysis of overall fertility, but the unexpected effect of introduction of the rams may have introduced bias favouring some treatments and not others. On the other hand, the ram effect, being a psychic phenomenon, is qualitatively different from the hormonal effects. It was therefore decided to carry out the analysis using the numbers of

TABLE 3

SUMMARY OF ANALYSIS OF VARIANGE OF THE
RESULTS OF EXPERIMENT 2

\begin{tabular}{|c|c|c|}
\hline Source of variation & d.f. & Mean square \\
\hline $\begin{array}{l}\text { Progesterone } \\
\text { Frequency of injections (F) } \\
\text { Dose per injection (D) } \\
\mathbf{F} \times \mathbf{D}\end{array}$ & $\begin{array}{l}1 \\
1 \\
1\end{array}$ & $\begin{array}{c}1449 \cdot 7 * \\
1308 \cdot 6 * \\
227 \cdot 2\end{array}$ \\
\hline $\begin{array}{l}\text { PMS } \\
\text { Time of injection }(T) \\
\text { Dose }(\mathrm{P}) \\
\mathrm{T} \times \mathbf{P}\end{array}$ & $\begin{array}{l}1 \\
1 \\
1\end{array}$ & $\begin{array}{r}253 \cdot 6 \\
303 \cdot 6 \\
30 \cdot 0\end{array}$ \\
\hline $\begin{array}{l}\text { Interaction } \\
\quad \mathbf{F} \times \text { PMS } \\
\text { Remainder } \\
\text { Error variance }\end{array}$ & $\begin{array}{l}3 \\
6 \\
\infty\end{array}$ & $\begin{array}{l}653.3^{*} \\
257.5 \dagger \\
117.2\end{array}$ \\
\hline
\end{tabular}

The response was the number of ewes lambing after mating on Days 2 to 6 as a proportion of the total ewes per group. The data were transformed to angles, $\mathrm{n}=7$.

$$
\text { * } P<0.001 ; \dagger 0.01<P<0.05 \text {. }
$$

ewes lambing after mating on Day 2 to Day 6, as a proportion of the total number of ewes per group. The analysis is shown in Table 3 . Dose and frequency of injection of progesterone were the major factors influencing the response- $20 \mathrm{mg}$ of progesterone given daily gave the best results. It is evident however that interaction existed between PMS and frequency of progesterone injections. With daily progesterone, results tended to be better when PMs was given on Day 0 whereas this was not so with injections every 2 days.

\section{EXPERIMENT 3-AUGUST 1961}

\section{Methods}

Forty-six aged Merino ewes were placed in yards and fed a grain-chaff ration ad libitum. Commencing on 16th August 1961, groups of twelve ewes received one of the following four treatments (injections 8.00 to $9.00 \mathrm{a.m}$. ): $1 \mathrm{or} 3 \mathrm{mg}$ of progesterone per day; 2 or $6 \mathrm{mg}$ of progesterone every 2 days. The final progesterone injections were administered at 8.00 a.m. on 28th August (Day 0). At 11.00 a.m. on Day 0, groups of four ewes within each progesterone treatment received 400,1200 or 3600 i.u. of PMs. The experiment was thus a $2^{2} \times 3$ 
factorial. On Day 2, six harnessed vasectomized rams were joined with the flock and the ewes examined twice daily for service marks, denoting oestrus. All ewes were ovariectomized on Day 7 and the ovaries examined macroscopically for recent ovulations and follicles greater than $0.75 \mathrm{~cm}$ diameter.

TABLE 4

NUMBER OF EWES IN OESTRUS AND NUMBERS OF OVULATIONS AND FOLLIGLES GREATER THAN 0.75 CM DIAMETER IN EWES IN EXPERIMENT 3

\begin{tabular}{|c|c|c|c|c|c|c|}
\hline \multirow{2}{*}{ Hormonal treatment } & \multirow{2}{*}{$\begin{array}{l}\text { No. } \\
\text { ewes }\end{array}$} & \multirow{2}{*}{$\begin{array}{l}\text { No. ewes in } \\
\text { oestrus on } \\
\text { Days } 2 \text { to } 5\end{array}$} & \multicolumn{2}{|c|}{$\begin{array}{l}\text { No. ovulations } \\
\text { in ewes in oestrus } \\
\text { on Days } 2 \text { to } 5\end{array}$} & \multicolumn{2}{|c|}{ No. follicles } \\
\hline & & & Mean & Range & Mean & Range \\
\hline $\begin{array}{lc}\text { Progesterone } & \text { PMs (i.u.) } \\
1 \mathrm{mg} / \text { day } & 400 \\
& 1200 \\
& 3600\end{array}$ & $\begin{array}{l}4 \\
4 \\
4\end{array}$ & $\begin{array}{l}0 \\
0 \\
2\end{array}$ & & & $\begin{array}{l}0 \cdot 2 \\
1 \\
26\end{array}$ & $\begin{array}{c}1 \\
1 \text { to } 2 \\
10 \text { to } 40\end{array}$ \\
\hline $\begin{array}{r}2 \mathrm{mg} \text { every } 2 \text { days } 400 \\
1200 \\
3600\end{array}$ & $\begin{array}{l}4 \\
4 \\
3\end{array}$ & $\begin{array}{l}2 \\
0 \\
0\end{array}$ & & & $\begin{array}{l}0 \cdot 5 \\
2 \\
10\end{array}$ & $\begin{array}{l}1 \\
2 \text { to } 6 \\
5 \text { to } 13\end{array}$ \\
\hline $3 \mathrm{mg} /$ day & $\begin{array}{l}4 \\
4 \\
3\end{array}$ & $\begin{array}{l}4 \\
3 \\
3\end{array}$ & $\begin{array}{l}1 \cdot 25 \\
0 \cdot 67 \\
0 \cdot 67\end{array}$ & $\begin{array}{c}1 \text { to } 2 \\
1 \\
1\end{array}$ & $\begin{array}{r}0 \\
2 \\
17\end{array}$ & $\begin{array}{c}1 \text { to } 4 \\
10 \text { to } 25\end{array}$ \\
\hline 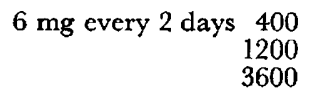 & $\begin{array}{l}4 \\
4 \\
4\end{array}$ & $\begin{array}{l}3 \\
4 \\
4\end{array}$ & $\begin{array}{l}0 \cdot 67 \\
3 \cdot 25 \\
5 \cdot 5\end{array}$ & $\begin{array}{l}1 \\
1 \text { to } 8 \\
1 \text { to } 11\end{array}$ & $\begin{array}{l}0.25 \\
1 \\
8\end{array}$ & $\begin{array}{l}1 \\
1 \text { to } 3 \\
5 \text { to } 17\end{array}$ \\
\hline \multicolumn{7}{|c|}{ Analyses of variance } \\
\hline \multirow{2}{*}{\multicolumn{2}{|c|}{ Source of variation }} & \multicolumn{2}{|c|}{ d.f. } & \multicolumn{3}{|c|}{ Mean square } \\
\hline & & $\stackrel{(a)}{\text { Ovulations } \dagger}$ & $\stackrel{(b)}{\text { Follicles }}$ & Ovu & ionst & $\begin{array}{c}(b) \\
\text { Follicles }\end{array}$ \\
\hline \multicolumn{2}{|c|}{ 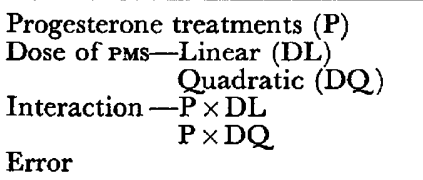 } & $\begin{array}{r}1 \\
1 \\
1 \\
1 \\
1 \\
14\end{array}$ & $\begin{array}{r}3 \\
1 \\
1 \\
6 \\
34\end{array}$ & \multicolumn{2}{|c|}{$\begin{array}{l}0.357 * \\
0 \cdot 149 \\
0 \cdot 001 \\
0 \cdot 440^{*} \\
0 \cdot 031 \\
0 \cdot 051\end{array}$} & $\begin{array}{l}0.054 \\
8 \cdot 715 * * * * \\
0.900 * * * \\
0 \cdot 070 \\
\\
0 \cdot 059\end{array}$ \\
\hline
\end{tabular}

The analyses of variances were carried out on $\log$ transformed data.

$+3 \mathrm{mg} /$ day and $6 \mathrm{mg} / 2$ day treatments only.

* $0.01<P<0.05$; *** $P<0.001$.

Results

Oestrus, ovulation and follicle data are shown in Table 4. In the groups receiving $1 \mathrm{mg}$ of progesterone per day or $2 \mathrm{mg}$ every 2 days more than half the ewes ovulated during the treatments, six ovulated at the expected time 3 to 6 days after the final progesterone and the remainder had not ovulated, though large follicles were present. Follicle growth was generally extensive in the groups receiving high dosage levels of PMS, whether a fully grown and presumably functional corpus luteum was present or not. 
One ewe that received $3 \mathrm{mg}$ of progesterone per day and one that received $6 \mathrm{mg}$ every 2 days ovulated during the treatment period. In spite of the considerable variation in the numbers of ovulations between ewes that received a high dosage of PMS, the progesterone treatments influenced ovulations. Only one double ovulation occurred in the ewes on $3 \mathrm{mg} /$ day but an average of 5.5 ovulations per ewe were observed in the four ewes that received 3600 i.u. of PMs following $6 \mathrm{mg}$ of progesterone every 2 days. There was a trend towards

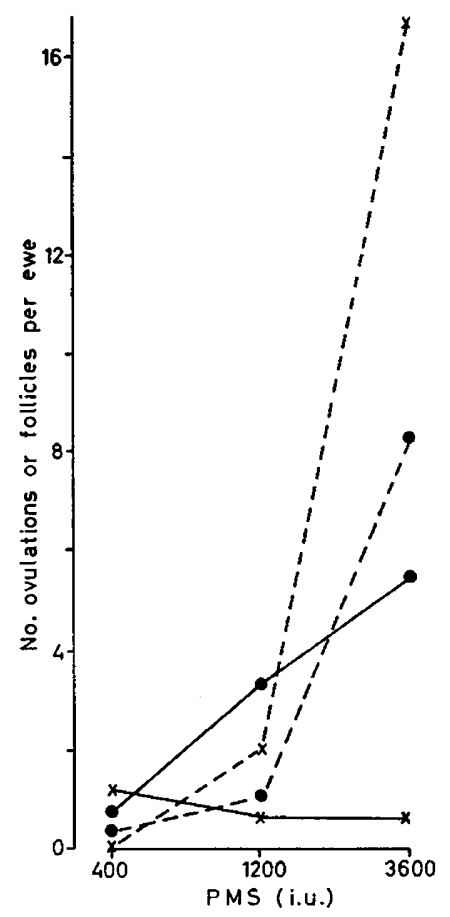

TEXT-Fig. 2. Mean number of ovulations and follicles greater than $0.75 \mathrm{~cm}$ diameter observed at laparotomy in the ewes in Experiment 3.

$\times \ldots . . \times$ Follicles in ewes that received $3 \mathrm{mg}$ progesterone per day.

$\times-\times$ Ovulations in ewes that received $3 \mathrm{mg}$ progesterone per day.

- . . - Follicles in ewes that received $6 \mathrm{mg}$ progesterone every 2 days.

- Ovulations in ewes that received $6 \mathrm{mg}$ progesterone every 2 days.

greater numbers of follicles in the daily injection groups. The mean numbers of ovulations and numbers of large follicles are shown in Text-fig. 2. Summaries of the relevant analyses of variance, after $\log$ transformation, are shown in Table 4.

EXPERIMENT 4-APRIL 1962

\section{Methods}

Sixty aged Merino ewes were brought into yards from pasture 2 weeks prior to commencement of injections of progesterone. From 22nd April 1962 to 1st May all ewes received $20 \mathrm{mg}$ of progesterone in oil intramuscularly every other day. Half received $10 \mathrm{mg}$ on 2nd, 3rd, 4th and 5th May and the remainder 
were given $14 \mathrm{mg}$ on 3rd and 5th May. On either 5th May (Day 0) or 6th May (Day 1) groups of five ewes received 400, 1200 or 3600 i.u. of PMs. Progesterone injections were given at $8.00 \mathrm{a} . \mathrm{m}$. and PMS at $11.00 \mathrm{a} . \mathrm{m}$. The experiment was

\section{TABLE 5}

NUMBERS OF EWES IN OESTRUS, TIME TO ONSET OF OESTRUS FROM FINAL PROGESTERONE INJECTION AND THE DURATION OF OESTRUS FOR EWES IN EXPERIMENT 4

\begin{tabular}{|c|c|c|c|c|c|}
\hline \multicolumn{3}{|c|}{ Treatment } & \multicolumn{3}{|c|}{ Result } \\
\hline \multirow{2}{*}{$\begin{array}{c}\text { Dose of } \\
\text { progesterone }\end{array}$} & \multicolumn{2}{|c|}{ PMS } & \multirow{2}{*}{$\begin{array}{l}\text { No. ewes } \\
\text { in oestrus }\end{array}$} & \multirow{2}{*}{$\begin{array}{c}\text { Mean period from final } \\
\text { progesterone injection to } \\
\text { onset of oestrus } \\
\pm \text { S.E. }(h r)\end{array}$} & \multirow{2}{*}{$\begin{array}{c}\text { Duration } \\
\text { of oestrus } \\
(h r)\end{array}$} \\
\hline & $\begin{array}{l}\text { Day of } \\
\text { injection }\end{array}$ & $\begin{array}{l}\text { Dose } \\
(\text { i.u. })\end{array}$ & & & \\
\hline \multirow[t]{2}{*}{$10 \mathrm{mg} / \mathrm{day}$} & 0 & $\begin{array}{r}400 \\
1200 \\
3600\end{array}$ & $\begin{array}{l}5 \\
4 \\
4\end{array}$ & $\begin{array}{l}58 \pm 4 \cdot 1 \\
62 \pm 9 \cdot 0 \\
50 \pm 1 \cdot 5\end{array}$ & $\begin{array}{l}25 \cdot 8 \\
23 \cdot 0 \\
59 \cdot 8\end{array}$ \\
\hline & 1 & $\begin{array}{r}400 \\
1200 \\
3600\end{array}$ & $\begin{array}{l}4 \\
5 \\
5\end{array}$ & $\begin{array}{l}66 \pm 7 \cdot 0 \\
62 \pm 2 \cdot 2 \\
58 \pm 2 \cdot 9\end{array}$ & $\begin{array}{l}32 \cdot 2 \\
41 \cdot 6 \\
98 \cdot 4\end{array}$ \\
\hline \multirow[t]{2}{*}{$14 \mathrm{mg}$ every 2 days } & 0 & $\begin{array}{r}400 \\
1200 \\
3600\end{array}$ & $\begin{array}{l}5 \\
5 \\
5\end{array}$ & $\begin{array}{l}61 \pm 4 \cdot 3 \\
52 \pm 1 \cdot 5 \\
56 \pm 3 \cdot 9\end{array}$ & $\begin{array}{l}29 \cdot 4 \\
31 \cdot 2 \\
62 \cdot 2\end{array}$ \\
\hline & 1 & $\begin{array}{r}400 \\
1200 \\
3600\end{array}$ & $\begin{array}{l}5 \\
5 \\
3\end{array}$ & $\begin{array}{l}68 \pm 2 \cdot 9 \\
64 \pm 1 \cdot 5 \\
57 \pm 2 \cdot 7\end{array}$ & $\begin{array}{l}16 \cdot 8 \\
49 \cdot 4 \\
86 \cdot 6\end{array}$ \\
\hline
\end{tabular}

There were five ewes per group.

TABLE 6

ANALYSES OF VARIANCE OF NUMBERS OF OVULATIONS, AND FOLLIGLES GREATER THAN 0.75 GM DIAMETER, AND DURATION OF OESTRUS IN EXPERIMENT 4

\begin{tabular}{|c|c|c|c|c|c|c|}
\hline \multirow[b]{2}{*}{ Source of variation } & \multicolumn{3}{|c|}{ d.f. } & \multicolumn{3}{|c|}{ Mean square } \\
\hline & Ovulations & Follicles & $\begin{array}{c}\text { Duration } \\
\text { of } \\
\text { oestrus }\end{array}$ & Ovulations & Follicles & $\begin{array}{c}\text { Duration } \\
\text { of } \\
\text { oestrus }\end{array}$ \\
\hline $\begin{array}{l}\text { Progesterone treatments } \\
\text { Time of injection of PMS } \\
\text { Dose of PMS-Linear } \\
\text { Quadratic } \\
\text { Interaction } \\
\text { Error }\end{array}$ & $\begin{array}{r}1 \\
1 \\
1 \\
1 \\
7 \\
47\end{array}$ & $\begin{array}{r}1 \\
1 \\
1 \\
1 \\
7 \\
47\end{array}$ & $\begin{array}{r}1 \\
1 \\
1 \\
1 \\
7 \\
43\end{array}$ & $\begin{array}{l}0 \cdot 406 * \\
0 \cdot 016 \\
0 \cdot 672 * * * \\
0 \cdot 011 \\
0 \cdot 024 \\
0 \cdot 054\end{array}$ & $\begin{array}{l}0.036 \\
0.000 \\
13.679 * * * \\
2.418 * * * \\
0.052 \\
0.085\end{array}$ & $\begin{array}{c}3 \\
3792^{* * *} \\
24950 * * * \\
3172 * * \\
573 \\
255 \cdot 2\end{array}$ \\
\hline
\end{tabular}

Ovulation and follicle data converted to logarithms.

* $0.01<P<0.05$; ** $0.001<P<0.01$; *** $P<0.001$.

thus a $2 \times 2 \times 3$ factorial; the ewes randomly allotted to the twelve groups prior to commencement of the experiment.

Commencing on the morning of Day 2, the ewes were tested for oestrus at 7.00 to 8.00 a.m., 10.00 to 11.00 a.m., 2.00 to 3.00 p.m., 5.00 to 6.00 p.m. and 
10.00 to 11.00 p.m. each day. Small groups of ewes were joined with harnessed vasectomized rams for $\frac{1}{2}$ to $1 \mathrm{hr}$, at each time (see Lamond \& Bindon, 1962, for details). The approximate times of both the onset and end of oestrus (and hence the duration) were determined. Two or 3 days after the end of oestrus the ewes were ovariectomized and the ovaries examined macroscopically for recent ovulations and large follicles (i.e. greater than $0.75 \mathrm{~cm}$ diameter).

\section{Results}

The majority of ewes came into oestrus 48 to $72 \mathrm{hr}$ after the final injection of progesterone and the time of onset did not differ significantly between treatment groups (Table 5). However, the average duration of oestrus was greater when PMS was given on Day 1 . In addition, the duration of oestrus was approximately two to three times the normal length in ewes given 3600 i.u. of PMS. Duration of oestrus is approximately $30 \mathrm{hr}$ in ewes of this strain at the Research Station after treatment with progesterone alone (Lamond \& Bindon, 1962).
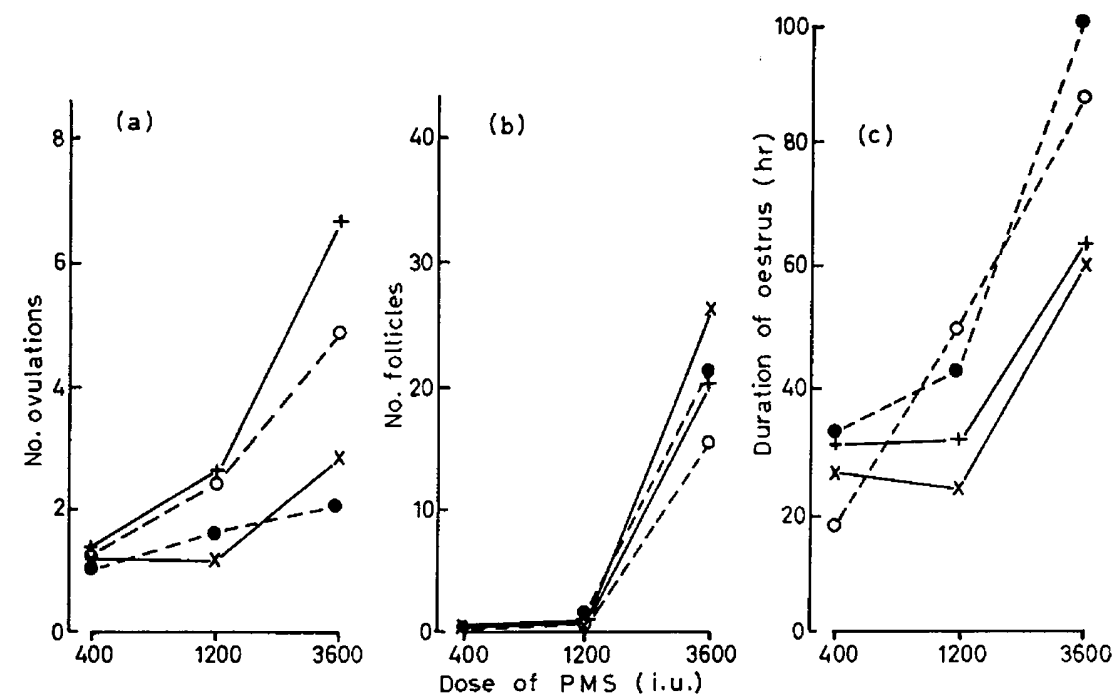

TEXT-Frg. 3. Mean numbers of ovulations (a) and large follicles (b) at laparotomy in the ewes in Experiment 4, and the average duration of oestrus (c).

$$
\begin{aligned}
& \times \ldots 10 \mathrm{mg} \text { of progesterone per day, pMs Day } 0 . \\
& +\ldots+\ldots \mathrm{mg} \text { of progesterone per day, PMs Day } 1 . \\
& +\ldots+14 \mathrm{mg} \text { of progesterone every } 2 \text { days, PMs Day } 0 .
\end{aligned}
$$

The mean numbers of ovulations are shown in Text-fig. 3. An analysis of variance (Table 6) was carried out after log transformation. The mean number of ovulations was greater after $14 \mathrm{mg}$ of progesterone every 2 days, and in both progesterone treatments, there was a linear relationship between log dose (of PMs) and log number of ovulations. The response to PMS was not affected by the time the PMs was given in relation to the final progesterone injection.

Average numbers of large follicles are also shown in Text-fig. 3 . The analysis of variance of $\log$ transformed data (Table 6) indicates a highly significant increase in large follicles associated with the highest dosage level of PMs. 


\section{DISCUSSION}

In Experiments 1 and 2 it was shown that adequate fertility was possible when PMS was given after suppression of ovarian cycles by progesterone. Certain treatment combinations gave better results than others. Therefore it may be assumed that optimal conditions may exist for normal fertility after hormonal control of synchronized ovarian activity. In Experiment 2, $20 \mathrm{mg}$ of progesterone daily for the final 4 days of a suppressive treatment followed by PMs on the day of the final injection gave good synchronization and fertility under circumstances of introduction of a strong psychic stimulus at a critical period in the treatment. These two experiments, however, did not give any clear indication of the factors controlling multiple ovulations, but the possibility of an interaction between frequency of injections of progesterone and PMs was evident from the results of the analysis of variance (Table 3 ).

It was shown in Experiments 3 and 4 that the number of ovulations was greater when progesterone was given on alternate days compared with daily injections, for comparable doses of PMS. This relationship was shown to hold both in May which is the middle of the breeding season and in August, which is near the end of the breeding season (Barrett, Reardon \& Lambourne, 1962; Lamond, 1964). The doses of progesterone used were two to three times greater in May than in August. These doses were selected on the basis of having approximately equal suppressive action for the respective stages of the breeding season (Lamond, 1962d). In May the time of onset of oestrus was similar for both progesterone treatments. The time of onset of oestrus was not determined accurately in August 1961, but was observed to follow the general pattern outlined by Lamond \& Lambourne (1961).

Differences in numbers of follicles and in duration of oestrus were independent of the method of suppression but were related to the PMs treatments in Experiment 4 . It would seem therefore that the effects due to differences in frequency of administration of progesterone were related only to the process of ovulation and not to follicle growth per se. Whether the effect on ovulation was due to increased storage of ovulating hormone in the anterior pituitary gland, or to an increase in the ability of the hypothalamus to influence production of ovulatory hormone, remains to be determined. Whatever the mechanism, the results indicate a method for hormonal control over numbers of ovulations, and should become a useful aid to studies of hypothalamic-pituitary-ovarian relationships.

The results have a direct bearing on superovulation studies in farm animals, particularly for egg transfer and multiple births. Moore \& Shelton (1962), using horse anterior pituitary gland extract (HAP) found that a significantly smaller proportion of eggs was fertilized when more than twenty (approximately) ovulations occurred. Gordon (1958a) and Gordon \& Williams (1961) have carried out large-scale studies in which PMS was given at an estimated 4 to 6 days prior to oestrus in order to induce multiple ovulations in sheep and cattle. However, it is difficult to control numbers of ovulations after an injection of HAP or PMS during the follicular stage of the oestrous cycle, because of wide variation between animals in their response to injected gonadotrophins. The use of progesterone, apart from the obvious advantages of synchronization, may reduce this variation. 
The present work demonstrates that seemingly small changes in the dosage levels of progesterone and PMS, the relative times of administration, and the method of giving suppressive doses of progesterone, may lead to relatively large changes in pituitary-ovarian function as measured by oestrus, follicle development and ovulation. Other factors, particularly those of external origin and acting through exteroceptive pathways (season, introduction of rams) have also been shown to influence the results of hormonal treatments. These points indicate the difficulty in making generalizations about the interaction between progesterone and PMS and perhaps other progestagens and gonadotrophins, on the basis of one or two dosage levels or in experiments in which too few factors are varied at the same time.

A final point should be made concerning the selection of ewes for multiple ovulation studies. There are breed and strain differences in numbers of ovulations and only a low proportion of the ewes in the strain of Merinos used in this study (fine wool) normally have multiple ovulations. It is probable that high doses of PMS are needed to produce multiple ovulations in such sheep. This raises the question whether such doses may cause hormonal imbalance leading not only to prolonged oestrus as demonstrated here but also to genital tract abnormalities that may reduce fertility. In such instances multiple ovulation and normal fertility may be mutually incompatible.

\section{ACKNOWLEDGMENTS}

Thanks are due to Mr K. Cummins, Tia, for providing the sheep in Experiment 1. Mr D. R. Lang and Mr I. Bennett provided valuable assistance. Colleagues in the Division of Animal Physiology made helpful criticisms of the manuscript.

\section{REFERENCES}

Barrett, J. F., Reardon, T. F. \& Lambourne, L. J. (1962) Seasonal variation in reproductive performance of Merino ewes in northern New South Wales. Aust. 7. exp. Agric. Anim. Husb. 2, 69.

Braden, A. W. H., Lamond, D. R. \& Radford, H. M. (1960) The control of ovulation in sheep. Aust. J. agric. Res. 11, 389.

Claringbold, P. J. \& Lamond, D. R. (1957) Optimum conditions for the bioassay of gonadotrophins. 7. Endocrin. 16, 86.

Cole, H. H. \& Miller, R. F. (1933) Artificial induction of ovulation and oestrus in the ewe during anoestrum. Amer. 7. Physiol. 104, 165.

Davies, H. L. (1960) Reduced fertility associated with the use of multiple injections of progesterone followed by pregnant mare serum. II. Aust. vet. 7. 36, 20.

Davies, H. L. \& Dun, R. B. (1957) A note on the infertility of ewes treated with multiple injections of progesterone followed by PMs. Aust. vet. F. 33, 92 .

DuTr, R. H. (1953) Induction of oestrus and ovulation in anoestrual ewes by use of progesterone and pregnant mare serum. 7. Anim. Sci. 12, 515.

Edgar, D. G. \& Ronaldson, J. W. (1958) Blood levels of progesterone in the ewe. J. Endocrin. $16,378$.

Gordon, I. (1958a) The use of progesterone and serum gonadotrophin (PMs) in the control of fertility in sheep. I. The hormonal augmentation of fertility in the ewe during the breeding season. 7 . agric. Sci. 50, 123.

Gordon, I. (1958b) The use of progesterone and serum gonadotrophin (PMs) in the control of fertility in sheep. II. Studies in the extraseasonal production of lambs. 7. agric. Sci. 50, 152.

Gordon, I. \& Williams, G. (1961) The Milk Marketing Board twin calf trial: an interim report. Vet. Rec. 73, 359.

Lamond, D. R. (1957) Relative potency of some commercial gonadotrophin preparations. Aust. vet. $\mathcal{F}$. 33, 127. 
Lamond, D. R. (1960) Fertility in ewes following controlled breeding techniques. Proc. Aust. Soc. Anim. Prod. 3, 120.

LAMOND, D. R. (1962a) Oestrus and ovulation following administration of placental gonadotrophins to Merino ewes. Aust. 7. agric. Res. 13, 707.

LAmond, D. R. (1962b) Effect of season on hormonally induced ovulation in Merino ewes. F. Reprod. Fertil. 4, 111 .

LAmond, D. R. (1962c) Anomalies in onset of oestrus after progesterone suppression of oestrous cycles in ewes, associated with introduction of rams. Nature, Lond. 193, 85.

LAMOND, D. R. (1962d) Suppression of oestrous cycles in sheep using progesterone. Artificial Breeding of Sheep in Australia. Ed. E. M. Roberts. University of New South Wales, Australia.

LAMOND, D. R. (1964) Seasonal changes in the oestrous response following progesterone suppression of ovarian function in the Merino ewe. 7 . Reprod. Fertil. (In press).

LAmond, D. R. \& Bindon, B. M. (1962) Oestrus, ovulation and fertility following suppression of ovarian cycles in Merino ewes by progesterone. 7. Reprod. Fertil. 4, 57.

Lamond, D. R. \& Lambourne, L. J. (1961) Suppression of oestrus in sheep with progesterone. Aust. $\mathcal{J}$. agric. Res. 12, 154.

Lamond, D. R. \& Urquhart, E. J. (1961) Sheep laparotomy cradle. Aust. vet. 7. 37, 430.

Moore, N. W. \& Shelron, J. N. (1962) The application of the technique of egg transfer to sheep breeding. Aust. 7. agric. Res. 13, 718.

Radford, H. M., Watson, R. H. \& Wood, G. F. (1960) A crayon and associated harness for the detection of mating under field conditions. Aust. vet. F. 36, 57.

Robinson, T. J. (1951) The control of fertility by gonadotrophin treatment of the ewe in the normal breeding season. 7. agric. Sci. 41, 6 .

Robinson, T. J. (1954) Fertility of anoestrous ewes following injection of progesterone and pregnant mare serum (PMs). Aust. 7. agric. Res. 4, 730.

Robinson, T.J. (1955) Endocrine relationships in the induction of oestrus and ovulation in the anoestrous ewe. 7 . agric. Sci. $46,38$.

Rosinson, T. J. (1956) The artificial insemination of the Merino sheep following the synchronization of oestrus and ovulation by progesterone injected alone and with pregnant mare serum gonadotrophin. Aust. 7. agric. Res. 7, 194.

Robinson, T. J. (1958) Studies in controlled artificial insemination of Merino sheep. Aust. $\mathcal{J}$. agric. Res. $9,693$.

Robinson, T. J. (1959) Reproduction in domestic animals, vol. 1. Eds. H. H. Cole and P. T. Cupps. Academic Press, New York.

Robinson, T.J. (1961) The time of ovulation and efficiency of fertilization following progesterone and pregnant mare serum treatment in the cyclic ewe. 7. agric. Sci. 57, 129.

Wallace, L. R. (1954) Studies in the augmentation of fertility of Romney ewes with pregnant mare serum. 7. agric. Sci. 45, 60. 